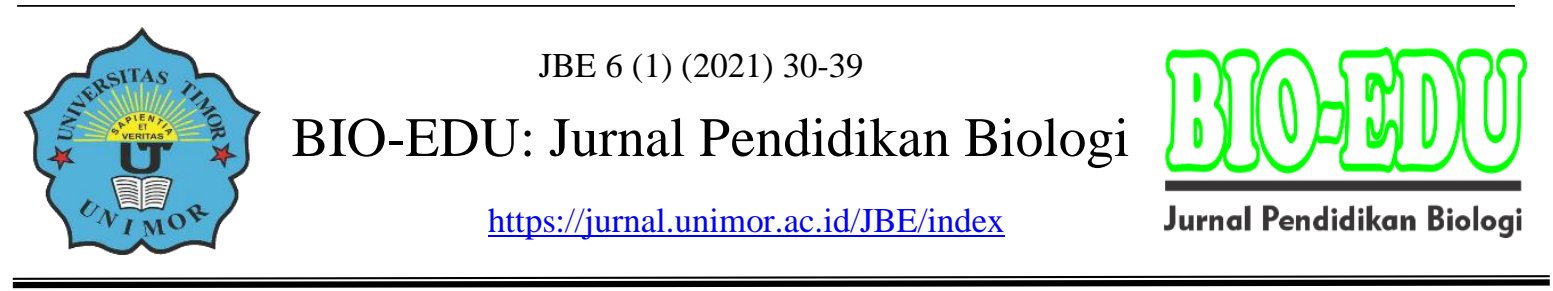

\title{
Kelimpahan Jenis Burung Diurnal Di Ruang Terbuka Hijau Tanah Pemakaman di Kota Malang, Jawa Timur
}

\author{
Zainal Abidin ${ }^{*}$, Anggraeni Hadi Pratiwi ${ }^{1}$, Medha Baskara ${ }^{2}$ \\ ${ }^{1}$ Program Studi Agroteknologi, Universitas Islam Raden Rahmat, Malang, Indonesia \\ ${ }^{2}$ Program Studi Agroekoteknologi, Universitas Brawijaya, Malang, Indonesia \\ zainal.abidin@uniramalang.ac.id
}

DOI: https://doi.org/10.32938/jbe.v6i1.1000

\begin{abstract}
Abstrak
Eksistensi Ruang Terbuka Hijau (RTH) yang di wilayah Kota Malang mulai menurun, ini dikarenakan proses pembangunan yang intensif. Tempat Pemakaman Umum (TPU) ialah salah satu RTH yang berfungsi lain yaitu sebagai kawasan resapan air, penghasil biomasa serta karbon terbanyak, dan habitat binatang liar contohnya burung. Penelitian kelimpahan burung diurnal dilaksanakan pada bulan September sampai bulan November 2020 di 3 TPU ialah (TPU Kasin, TPU Samaan, dan TPU Sukun). Metode perhitungan burung mengunakan IPA (Index Point of Abundance) dan Point Count. Identifikasi memakai buku "panduan lapangan burung-burung di Sumatra, Jawa, Bali, Kalimantan". Hasil pengamatan burung diurnal di 3 lokasi TPU terdapat 11 famili, 15 spesies, 267 individu. Indeks keanekaragaman Shanon-Wiener di TPU Sukun, Kasin, dan Samaan terletak pada tingkatan keanekaragaman yang terkategori sedang $\left(\mathrm{H}^{\prime}=1.5-3.5\right)$. Tingkatan kemerataan spesies dari ketiga TPU ialah $(\mathrm{E}>0.6)$ terkategori tinggi, sebaliknya nilai indeks kekayaan jenisnya $(\mathrm{R}<3.5)$ ialah terkategori rendah. Burung sriti (Hirundo tahitica) serta burung gereja (Passer montanus) populasinya lebih besar dibanding spesies yang lainnya. Kesesuaian lahan serta tingkatan gangguan dari penduduk kota terhadap burung disebagian areal TPU, mengakibatkan sebagian spesies burung tertentu yang bisa bertahan hidup dengan lingkungannya. Pengelolaan sumberdaya alam secara optimal mampu meningkatkan mutu kawasan lahan tersebut.
\end{abstract}

Kata Kunci; Ruang Terbuka Hijau; Burung Diurnal; Tempat Pemakaman Umum

\begin{abstract}
The reduction of green area in Malang City due to intensify of construction process. Public cemetery is kind of green area which has function as drainage, and wild animal habitat like birds, and also produce Biomasa and amount of carbon. Research on diurnal bird abundance was carried out from September to November 2020 on 3 Public cemeteries (Kasin Public cemetery, Samaan Public cemetery, and Sukun Public cemetery). The bird abundance calculation method uses IPA (Index Point of Abundance) and Point Count. Process of identification by using panduan lapangan burung-burung di Sumatra, Jawa, Bali, Kalimantan's book. The results of diurnal bird observations at 3 Public cemeteries are contained 11 families, 15 species, 267 individuals. The Shannon-Wiener diversity index in Sukun, Kasin, and Samaan Public cemeteries lies at the level of diversity which is categorized as medium $\left(H{ }^{\prime}=1.5-3.5\right)$. The level of evenness of the species of the three Public cemeteries are $(E>0.6)$ in the high category, on the other hand, the index value of species richness $(\mathrm{R}<3.5)$ is the low category. Sriti birds (Hirundo tahitica) and sparrows (Passer montanus) have a larger population than other species. The land suitability and the disturbance level from urban residents to birds in parts of the Public cemeteries are resulted only certain
\end{abstract}

30 | A b id in/JBE $6\left(\begin{array}{lllllll}1 & 0 & 0 & 2 & 1\end{array}\right) \quad 30-39$ 
bird species that able to survive in their environment. The optimization of natural resources management can improve the quality of its land.

Keywords: Green Area; Diurnal Bird, Public Cemetery

\section{PENDAHULUAN}

Kota Malang mempunyai penduduk terbanyak kedua setelah Kota Surabaya. Berdasarkan data Badan Pusat Statistik Kota Malang pada bulan September 2020 jumlah penduduk Kota Malang yaitu sebanyak 843. 810 jiwa (BPS, 2021). Melihat perkembangannya yang sangat pesat, akibatnya yang ditimbulkan ialah merubah susunan tata kota. Selaras bersama perkembangan di wilayah Malang dengan berbagai pengembangan serta pembangunan di wilayah pemakaman seharusnya menjadi program unggulan pembangunan wilayah berkesinambungan dengan areal sekitar serta binatang liar (Wibowo, 2014: 1-2).

Keberadaan binatang liar di area RTH ini adalah salah satu kekayaan hayati yang mana mempunyai fungsi ekologis yang sangat penting di area perkotaan. Tempat Pemakaman Umum (TPU) merupakan salah satu RTH yang mempunyai fungsi lain yaitu sebagai daerah resapan air, penghasil biomasa dan karbon terbesar, serta habitat bagi satwa liar seperti burung. Parameter adanya keberadaan burung menjadi salah satu tolak ukur terhadap kualitas lingkungan yang dikatakan seimbang. Kelimpahan dan keanekaragaman burung dan serangga menjadi indikator yang penting bagi lingkungan sekitar.

Lingkungan yang seimbang terdiri dari komponen tumbuhan, satwa liar, dan pengurai. Secara ekologis seluruh komponen yang ada di ekosistem mempunyai peran penting dan saling berkaitan. Keberadaan pohon di area pemakaman menjadi tempat yang strategis dan relung bagi spesies burung dalam melakukan seluruh aktivitasnya, sedangkan keberadaan serangga mempunyai peran penting baik sebagai pengurai, polinator, dan sebagai pakan burung jenis insektivora (Halle, 2000; 21).

Berdasarkan dari hasil penelitian Handoyo (2016: 85-89) di RTH di Kota Malang menyatakan bahwa didapati beberapa spesies burung yang terdiri dari 26 spesies dan 16 suku. Ditambahkan hasil penelitian Wisnubudi (2013: 50-55), menyatakan bahwa jenisjenis burung yang ada sangat dipengaruhi oleh keterbukaan tajuk pohon. Semakin banyak populasi burung, maka dapat disimpulkan semakin banyak ditemukannya tajuk pohon yang ada.

Keberadaan populasi burung diurnal di TPU Kota Malang, Jawa Timur sampai saat ini belum ditemukan secara nyata tingkat keanekaragaman dan kelimpahannya. Oleh sebab itu, sangat penting dilalaksanakan pengamatan terkait dengan kelimpahan spesies burung-burung diurnal di TPU Kota Malang. Kelimpahan dan keanekaragaman jenis burung ini menjadi salah satu upaya konservasi burung.

\section{METODE}

\section{Waktu dan Tempat Penelitian}

Pengamatan burung ini dilaksanakan tiga bulan (bulan September sampai November 2020) di tiga tempat pemakaman umum yaitu (TPU Kasin, TPU Samaan, dan TPU Sukun) Kota Malang, Jawa Timur. Adapun untuk peta lokasi pengambilan data di tiga TPU kota Malang ditampilkan di (Gambar 1). 


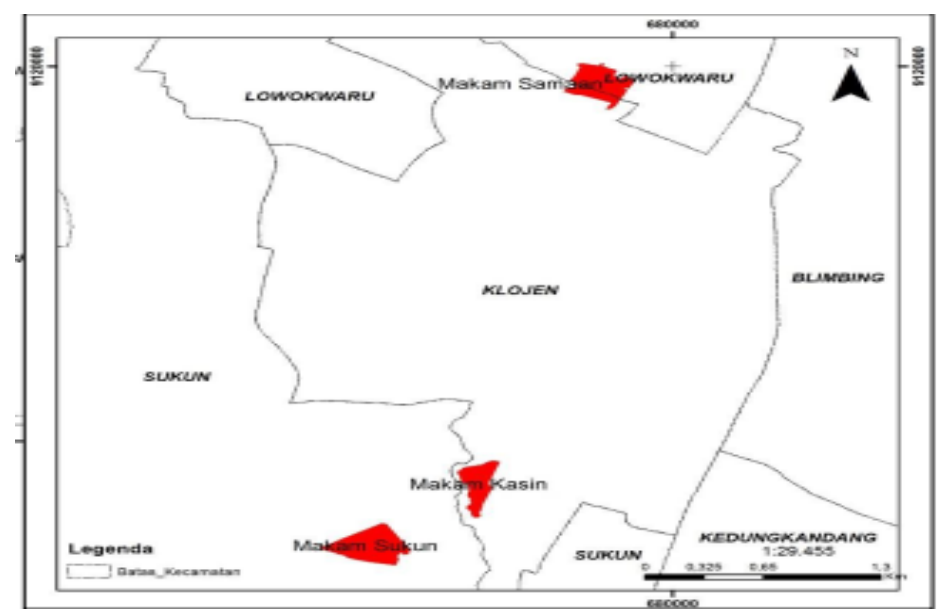

Gambar 1. Denah Lokasi Pengamatan di TPU

\section{Alat dan Bahan}

Alat-alat yang diperlukan untuk pengamatan ini berupa kamera digital, alat tulis, teropong, lembar pengamatan, dan buku panduan lapangan burung-burung di Sumatra, Jawa, Bali, Kalimantan, dan Malaysia (2000). Beberapa spesies burung-burung diurnal yang ada di ketiga TPU menjadi bahan yang diamati.

\section{Pelaksanaan Penelitian}

Pengamatan burung diurnal ini dilakukan sebanyak dua kali yaitu pagi hari (jam 6.00 08.00 WIB) dan sore hari (jam 15.00-17.00 WIB), karena frekuensi aktifitas populasi burungburung diurnal banyak terlihat pada waktu tersebut. Data pengamatan yang ditulis meliputi jumlah burung diurnal, jenis burung diurnal, jenis makan burung diurnal. Kemudian identifikasi jenis burung-burung yang ada di TPU langsung dilakukan di lokasi pengamatan.

\section{Analisis Data}

Metode perhitungan burung diurnal mengunakan Point Count dengan metode IPA (Index Point of Abundance). Kondisi sekitar di TPU zona pengamatan dilakukan menggunakan metode rapid assessment untuk memperoleh deskripsi yang mendetail beberapa tipe vegetasi pohon kawasan TPU (Brower, 1990; 273). Hasil data pemantauan burung yang didapatkan, kemudian diselesaikan kebentuk grafik dan tabel. Analisis data dengan indeks Keanakaragaman Shannon-Wienner (Odum, 1994: 34) berikut rumus digunakan:

Keterangan:

$$
\mathrm{H}^{\prime}=-\sum \mathrm{Pi} \ln (\mathrm{Pi}), \operatorname{dimana} \mathrm{Pi}=(\mathrm{ni} / \mathrm{N})
$$

H' = Indeks Keanekaragaman Shannon-Wienner

ni $=$ Jumlah individu jenis ke-i

$\mathrm{N}=$ Jumlah individu seluruh spesies

Kreteria nilai indeks keanekaragaman Shannon-Wienner $\left(H^{\prime}\right)$.

$\mathrm{H} \leq 1 \quad$ : Nilai keanekaragaman rendah

$1<\mathrm{H}<3$ : Nilai keanekaragaman sedang

$\mathrm{H} \geq 3 \quad$ : Nilai keanekaragaman tinggi

32 | A b id in/JBE 6(1) ( 2021 ) 30-39 
Untuk mendapati tingkat penyebaran spesies burung diukur dengan menggunakan nilai kemerataan antar jenis burung (Fachrul, 2007: 198) didapatkan dengan memakai rumus sebagai berikut:

Keterangan:

$$
\mathrm{E}=\frac{\mathrm{H}^{\prime}}{\ln \mathrm{S}}
$$

$\mathrm{S}$ = Banyaknya spesies burung tiap plot

$\mathrm{E}=$ Nilai kemerataan antara spesies

Untuk mencari nilai indeks kekayaan spesies burung menggunakan rumus indeks Margalef (Boontawee, et al., 1995: 103). Semakin tingginya keanekaragaman spesies burung maka ini menunjukkan semakin besarnya nilai kekayaan jenisnya setiap plot. Adapun rumus indeks Margalef sebagai berikut;

$$
\mathrm{R} 1=\frac{\mathrm{S}-1}{\ln (\mathrm{N})}
$$

\section{HASIL DAN PEMBAHASAN}

\section{Hasil}

\section{Keanekaragaman burung diurnal}

Hasil pengamatan yang ditemukan dari ketiga TPU Kota Malang (TPU Samaan, TPU Kasin, serta TPU Sukun) telah diketahui sebanyak 11 famili dan 15 spesies. Berdasarkan hasil pengamatan pada (Tabel 1) diperoleh dari hasil pengamatan burung Sriti atau Layang-layang (Hirundo tahitica) dan burung Gereja Erasia (Passer montanus) yang menunjukkan jumlah individu yang cukup tinggi yang berkunjung di ketiga TPU dibanding dengan individu lainnya. Adapun rekapitulasi keanekaragaman burung diurnal yang ada di TPU Kota Malang tersaji di (Tabel 1) sebagai berikut:

Tabel 1. Keanekaragaman spesies burung ditiga TPU Kota Malang

\begin{tabular}{llll}
\hline \multirow{2}{*}{ No $\quad$ Famili, Spesies $\quad$ Nama daerah } & \multicolumn{2}{l}{ Interval $\sum$ burung di lokasi } & Penggolongan \\
\cline { 3 - 4 } & Kasin $\quad$ Sukun Samaan & Senis pakan
\end{tabular}

Fam. Columbidae

1. Geopelia striata Perkutut

$$
+
$$

$++$

G

Fam. Ploceidae

2. Lonchura

leucogastriodes

(Emprit)

$+$

$++$

$+$

G

Fam. Alcedinidae

3. Halcyon cyanoventris *)

Fam. Hirundinidae

4. Dicaeum trochileum
$($ Tengkek buto $)+{ }_{+}+$

$\mathrm{K}, \mathrm{I}$

(Kemade)

$+\quad+$

I, F 
Lanjutan Tabel 1. Keanekaragaman spesies burung ditiga TPU Kota Malang

\begin{tabular}{|c|c|c|c|c|c|c|}
\hline \multirow{2}{*}{ No } & \multirow{2}{*}{ Famili, Spesies } & \multirow{2}{*}{ Nama daerah } & \multicolumn{3}{|c|}{ Interval $\sum$ burung di lokasi } & \multirow{2}{*}{$\begin{array}{c}\text { Penggolongan } \\
\text { jenis pakan }\end{array}$} \\
\hline & & & Kasin & Sukun & Samaan & \\
\hline & $\begin{array}{l}\text { Fam. } \\
\text { Chloropseidae }\end{array}$ & & & & & \\
\hline 5. & $\begin{array}{l}\text { Aegithina } \\
\text { viridissima } \\
\text { Fam. Dicaeidae }\end{array}$ & (Sirpu) & ++ & + & + & $\mathrm{U}$ \\
\hline \multirow[t]{2}{*}{6.} & $\begin{array}{l}\text { Streptopelia } \\
\text { chinensis }\end{array}$ & (Derkuku) & ++ & + & + & G \\
\hline & Fam. Nektariniidae & & & & & \\
\hline 7. & Nektarinia sperata & Madu sringanti & & + & & $\mathrm{N}$ \\
\hline \multirow[t]{2}{*}{8.} & Hirundo tahitica & (Sriti) & +++ & +++ & +++ & I \\
\hline & $\begin{array}{l}\text { Fam. } \\
\text { Zosteropoidae }\end{array}$ & & & & & \\
\hline 9. & $\begin{array}{l}\text { Zosterops flavus } \\
\text { Fam. Laniidae }\end{array}$ & (Perci) & ++ & & & $\mathrm{F}, \mathrm{I}, \mathrm{N}$ \\
\hline \multirow[t]{2}{*}{10.} & Lanius Schach & Bentet Kelabu & & + & & I \\
\hline & Fam. Pycnonotidae & & & & & \\
\hline 11. & $\begin{array}{l}\text { Pycnonotus } \\
\text { aurigaster }\end{array}$ & $\begin{array}{l}\text { Cucak } \\
\text { kutilang }\end{array}$ & ++ & ++ & ++ & $\mathrm{I}, \mathrm{F}$ \\
\hline 12. & $\begin{array}{l}\text { Orthotomus } \\
\text { ruficeps }\end{array}$ & (Cimblek) & + & + & & I \\
\hline 13. & $\begin{array}{l}\text { Pycnonotus } \\
\text { goiavier } \\
\text { Fam. Silviidae }\end{array}$ & (Trocokan) & ++ & +++ & + & $\mathrm{I}, \mathrm{F}$ \\
\hline 14. & Passer montanus & Gereja erasia & ++ & +++ & +++ & $\mathrm{G}$ \\
\hline 15 . & $\begin{array}{l}\text { Lonchura } \\
\text { Punctulata }\end{array}$ & $\begin{array}{l}\text { Bondol } \\
\text { peking }\end{array}$ & + & + & & $\mathrm{G}$ \\
\hline & Jumlah Jenis burung & per Wilayah & 12 & 13 & 10 & \\
\hline
\end{tabular}

\section{Sumber : Data Primer, yang sudah diolah}

Keterangan data tabel:

Interval jumlah populasi spesies burung yang dijumpai pada saat pengamatan: $+=$ Dijumpai 1-5 ekor, $++=$ Dijumpai 6-10 ekor, $+++=$ Dijumpai lebih 10 ekor Jenis makanan burung: 
$\mathrm{I}=$ Insectivora (Serangga, ulat), $\mathrm{K}=$ Karnivora (daging), $\mathrm{N}=$ Nektarivora (sari madu), $\mathrm{F}=$ Frugivora (Buah-buahan), $\mathrm{G}=$ Granivora (Biji-bijian).

*) = Termasuk pada spesies burung yang dilindungi oleh Pemerintah tertuang pada nomor 7 tahun 1999 tentang perihal proses pengawetan satwa dan tumbuhan.

Berdasakan dari jumlah jenis dan individu per plot, maka dapat diketahui lokasi pengamatan dengan jumlah jenis dan individu paling terbanyak sendiri yaitu di TPU Sukun mana terdiri dari 13 jenis burung dan 102 individu. Terbanyak pada saat pengamatan pagi hari, adapun data-data lainnya dapat dilihat pada (Tabel 2).

Tabel 2. Jumlah jenis dan jumlah individu burung di lokasi plot pengamatan

\begin{tabular}{lcccccc}
\hline Lokasi & \multicolumn{2}{c}{ Pengamatan Pagi Hari } & \multicolumn{2}{c}{ Pengamatan Sore hari } & \multicolumn{2}{c}{ Total } \\
\cline { 2 - 7 } TPU & $\begin{array}{c}\sum \text { Spesies } \\
(\mathrm{S})\end{array}$ & $\begin{array}{c}\sum \text { Individu } \\
(\mathrm{N})\end{array}$ & $\begin{array}{c}\sum \\
\text { Spesies } \\
(\mathrm{S})\end{array}$ & $\begin{array}{c}\sum \text { Individu } \\
(\mathrm{N})\end{array}$ & $\begin{array}{c}\sum_{\text {Spesies }} \\
(\mathrm{S})\end{array}$ & $\begin{array}{c}\sum \\
\text { Individu } \\
(\mathrm{N})\end{array}$ \\
\hline Kasin & 11 & 37 & 12 & 48 & 12 & 85 \\
Samaan & 10 & 45 & 9 & 35 & 10 & 80 \\
Sukun & 13 & 58 & 9 & 44 & 13 & 102 \\
\hline
\end{tabular}

Jenis pakan burung juga bervariasi seperti jenis pemakan serangga, buah, biji, nektar dan sebagainya. Untuk itu perlu diamati dan digolongkan jenis-jenis burung yang sudah teridentifikasi berdasarakan jenis pakannya. Pengamatan berbagai jenis burung di 3 lokasi TPU dapat diklasifikasikan berdasarkan jenis pakannya seperti : jenis burung pemakan serangga \& ulat ( $\mathrm{I}=$ insectivora), pemakan daging ( $\mathrm{K}=$ Karnivora) ; pemakan sari madu bunga / nektar $(\mathrm{N}=$ Nektarivora), pemakan buah-buahan $(\mathrm{F}=$ Frugivora) ; dan pemakan biji-bijian ( $\mathrm{G}=$ Granivora).

Selain itu ada beberapa jenis burung yang mempunyai kecenderungan mengkonsumsi lebih dari 1 jenis makanan atau mempunyai kombinasi pakan lebih dari 1 jenis pakan. Secara grafis presentase pengelompokan burung berdasarkan jenis pakannya dapat dilihat pada grafik dari (Gambar 2) berikut.

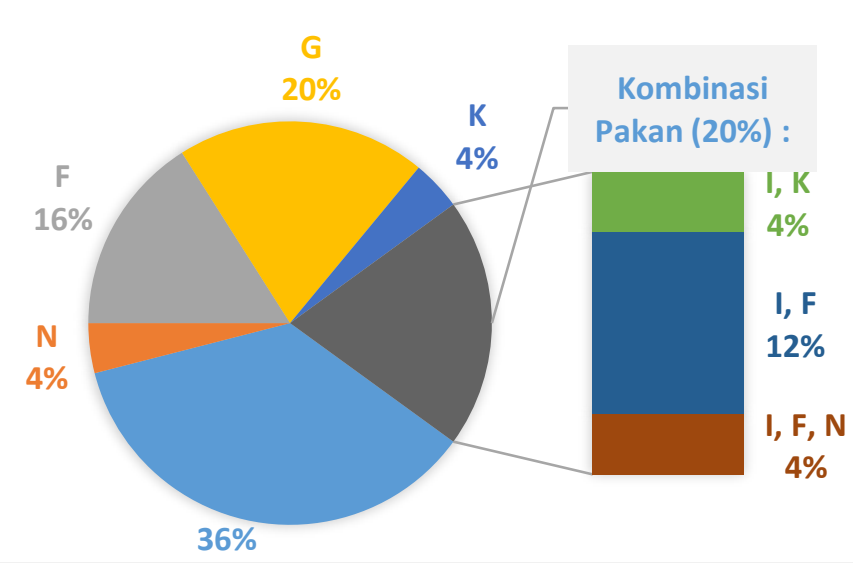

Gambar 2. Persentase jenis burung berdasarakan pakannya 


\section{Analisis Data Pengamatan Burung Diurnal}

Keragaman burung diurnal di masing-masing TPU disimpulkan sebagai tingkat kesesuaian burung dalam memilih TPU sebagai tempat untuk beraktifitas. Keanekaragaman jenis pada masing-masing lokasi pengamatan bagi burung perkotaan sesungguhnya memperlihatkan kemampuan lahan TPU perkotaan sebagai habitat burung. Pengolahan data burung di lapangan dari 3 lokasi TPU menghasilkan nilai indeks keanekaragaman ( $\left.\mathrm{H}^{\prime}\right)$, nilai indeks kemerataan $(\mathrm{E})$ dan nilai indeks kekayaan jenis margallef $(\mathrm{R})$ seperti yang bisa dilihat pada (Tabel 3) berikut:

Tabel 3. Indeks H. E dan R dari data hasil pengamatan burung di masing lokasi

\begin{tabular}{|c|c|c|c|c|c|c|c|}
\hline \multirow[b]{2}{*}{ Lokasi TPU } & \multicolumn{4}{|c|}{ Nilai Hasil Pengamatan } & \multicolumn{3}{|c|}{ Nilai Indeks } \\
\hline & $\mathrm{N}$ & $S$ & Ln N & $\operatorname{Ln} S$ & $\mathrm{H}^{\prime}$ & $\mathrm{E}$ & $\mathrm{R}$ \\
\hline Sukun & 102 & 13 & 4.62 & 2.56 & 1.96 & 0.76 & 2.59 \\
\hline Kasin & 85 & 12 & 4.44 & 2.48 & 2.21 & 0.89 & 2.47 \\
\hline Samaan & 80 & 10 & 4.38 & 2.30 & 2.02 & 0.87 & 2.05 \\
\hline
\end{tabular}

Keterangan : $\mathrm{N}=\sum$ individu ; $\mathrm{S}=\sum$ spesies burung ; $\mathrm{H}^{\prime}=$ Indeks keanekaragaman; $\mathrm{E}=$ Indeks Kemeretaan; $\mathrm{R}=$ Indeks kekayaan jenis

Berdasarkan hasil (Tabel 3) kita dapat menganalisis hasil keanekaragaman (H') di TPU Sukun, Kasin dan Samaan berada pada tingkat keanekargaman yang tergolong sedang $\left(H^{\prime}=1.5-3.5\right)$. Untuk tingkat kemerataan spesies di ketiga TPU tersebut $(E>0,6)$ tergolong tinggi. Sedangkan nilai indeks kekayaan jenis di ketiga TPU tersebut $(\mathrm{R}<3.5)$ tergolong rendah.

\section{Pembahasan}

\section{Keanekaragaman burung diurnal}

Berdasarkan dari hasil pengamatan dan identifikasi dilokasi ketiga TPU spesies burung sriti (Hirundo tahitica) Famili Nectariniidae dan spesies burung gereja erasisa (Passer montanus) Famili Silviidae lebih dominan berkunjung di ketiga TPU. Rata-rata berkunjung di TPU sebanyak 15 sampai 40 ekor perhari. Hasil dari penelitian Indra et.al, (2020; 46) burung sriti (Hirundo tahitica) ini semula ada di negara Jepang kemudian mereka bermigrasi ke daerah tropis dan subtropis diantaranya negara Indonesia, Malaysia, Singapura, sampai ke Australia ini semuanya terjadi pada bulan September sampai dengan bulan Oktober. Sedangkan pengamatan burung diurnal di ketiga TPU ini mulai bulan September sampai November. Puncak migraasi burung sriti ini pada bulan Desember dan pada bulan Januari mulai berkurang. Ditambahkan dari hasil penelitian Tobolka, (2011; 152) menyatakan jenis burung Gereja Erasia (Passer montanus) yaitu salah satu burung pemakan biji yang mempunyai tingkatan adaptasi yang sangat tinggi dengan ketersediaan bahan makanan di alam, perubahan cuaca yang ekstrim, serta keberadaan predatornya. 
Data hasil pengolahan pengamatan lapang menunjukkan bahwa ketiga lokasi pengamatan di atas menunjukkan bahwa keanekaragaman burung berada pada tingkatan sedang. Tingkatan keanekaragaman yang sedang ini menggambarkan bahwa potensi lahan makam mempunyai kecenderungan hanya di datangi jenis burung perkotaan pada umumnya. Kesesuaian lahan dan tingkat gangguan dari penduduk kota terhadap burung di beberapa areal ruang terbuka hijau (RTH) termasuk lahan makam, menyebakan hanya jenis burung-burung tertentu yang bisa menyesuaikan diri dengan lingkungannya.

Pengelolaan sumberdaya alam pada lahan makam dilakukan untuk meningkatkan kualitas lingkungan lahan, telah menjadi hal penting bagi ketersediaan habitat bagi burung-burung di perkotaan. Hasil perhitungan indeks kemerataan di ketiga lokasi makam menunjukkan hasil tingkat kemerataan yang sama-sama tinggi. Hal tersebut menunjukkan bahwa aktifitas dari segi jumlah individu dan jenis burungnya cukup menyebar baik. Penyebaran aktifitas akan menjadi baik jika tempat untuk beraktifitas seperti bertengger, mencari makan, bersarang dan lainnya, tersedia cukup baik dan memadai. Ketersediaan tempat yang sesuai bagi aktiftitas burung berhubungan juga dengan keberadaan vegetasi (pohon) yang tumbuh di lahan makam (Ekowati et,al, 2016; 92-93).

Jenis pohon yang disukai burung akan menentukan tingkat aktifitas burung sekaligus memancing kedatangan jenis burung lain untuk ikut beraktifitas di dalamnya. Salah satu faktor ketertarikan burung terhadap vegetasi pohon adalah tersedianya sumber makanan berupa serangga, buah, biji, dan nektar. Struktur dan komposisi vegetasi pohon ini dapat merubah populasi dan jenis burung di areal yang dijadikan habitatnya. Hal tersebut dikarenakan setiap populasi burung pasti memiliki relung (niche) tidak sama.

Berdasarkan hasil penelitian Widyastuti (2013; 24-27) Semakin banyak jenis vegetasi yang ada dalam suatu areal semakin mudah bagi burung dalam menentukan relungnya. Pemilahan relung ini memungkinkan spesies burung untuk hidup berdampingan dalam habitat yang sama. Beberapa spesies burung juga mempunyai proporsi yang sama dalam penggunaan habitat mikro.

\section{Analisis Data Pengamatan Jenis Burung}

Data indeks kekayaan jenis dari data pengamatan di ketiga lokasi makam tergolong pada tingkat kekayaan jenis yang rendah. Kekayaan jumlah individu dari masing-masing jenis burung tidak menunjukkan jumlah yang cukup signifikan. Dari pengamatan di 3 lokasi TPU, hanya jenis Sriti (Hirundo tahitica) yang menunjukkan jumlah individu yang cukup tinggi dibanding dengan individu jenis burung lainnya.

Ditambahkan hasil penelitian Tuhumury $(2014 ; 17)$ spesies burung Sriti sering bertengger dan bergerombol di area TPU, ini merupakan ciri khas utama burung Sriti yaitu burung yang hidup koloni atau berkelompok sesama spesiesnya ataupun dengan kelompok jenis burung walet. Selain jenis burung Sriti, jenis lain seperti burung gereja (Paser montanus), juga terlihat cukup tinggi jumlah individunya di masing-masing lokasi pengamatan.

Burung gereja atau sparrow mempunyai sifat lebih mudah beradaptasi dan 
berkembang biak terutama dengan lingkungan perkotaan. Ketersedian sumber makanan bagi burung sangatlah penting karena setiap individu membutuhkan energi dalam setiap berlangsungnya metabolisme dasar dan sedikit tambahan kalori untuk melakukan aktifitas hariannya. Jika sumber makanan tidak terpenuhi jenis satwa liar akan mati atau mencari habitat lain yang mampu menyediakan makanan. Ketersedian makanan burung dari lingkungan lahan yang baik dapat terbentuk dari dari sebuah pengelolaan sumberdaya secara bijak yang secara tidak langsung mendukung upaya pelestarian burung perkotaan (Dewi et,al. 2013; 103-108).

\section{KESIMPULAN DAN SARAN}

\section{Kesimpulan}

Berdasarkan hasil serta pembahasan dapat diperoleh data 11 famili, 15 spesies, 267 individu. Indeks keanekaragaman Shanon-Wiener di TPU Sukun, Kasin, dan Samaan terletak pada tingkatan keanekaragaman yang terkategori sedang $\left(\mathrm{H}^{\prime}=1.5-\right.$ 3.5). Tingkatan kemerataan spesies dari ketiga TPU ialah $(\mathrm{E}>0.6)$ terkategori tinggi, sebaliknya nilai indeks kekayaan jenisnya $(\mathrm{R}<3.5)$ ialah terkategori rendah. Burung sriti (Hirundo tahitica) serta burung gereja (Passer montanus) populasinya lebih besar dibanding spesies yang lainnya.

\section{Saran}

Perlu adanya pengamatan burung-burung diurnal di ketiga TPU di kota Malang pada musim kemarau sekitar bulan Februari sampai bulan Maret. Hal ini dikarenakan, jumlah keanekaragaman burung-burung diurnal pada musim penghujan dengan musim kemarau sangatlah beda secara signifikan.

\section{DAFTAR RUJUKAN}

[BPS] Badan Pusat Statistik. (2021). Jumlah penduduk kota Malang, Jawa Timur. 2015. BPS.

Boontawee B, Phengkhlai C, Kao-sa-ard A. (1995). Monitoring and measuring forest biodiversity in Thailand. Bogor (ID): CIFOR.

Brower, J. E., et. al. (1990). Field And Laboratory Method For General Ecology. Book. Wm. C. Brown Publisher. America. 273 p.

Dewi, et.al. (2013). Penggunaan Sebuah Jala Kabut untuk Studi Populasi Burung Gereja di Kampus IPB Bogor. Biologi Bogor: IPB Press.

Ekowati, et.al. (2016). Keanekaragaman Spesies Burung di Kawasan Telaga Warna, Desa Tugu Utara, Cisarua, Bogor. Journal of Biology, 9(2), 87-94. doi.org/10.15408/kauniyah.v9i2.3355.

Fachrul, M.F. (2007). Metode Sampling Penelitian Bioekologi. Jakarta: Bumi Aksara.

Gullan, P.J. and Cranston. (1994). The Insect; An Outline al-Qur'an Entomology. London; Chapman.

Halle, S. and Stenseth. (2000). Activity Pattern in Small Mammals. Berlin; Spinger. Handoyo, et. Al. (2016). Analisis Potensi Ruang Terbuka Hijau Kota Malang Sebagai Areal Pelestarian Burung. J-PAL, 7(2): 85-89. 
Indra, et.al. (2020). Jenis Burung di Kampus Universitas Tanjungpura. Journal Protobiont. Vol. 9(1): 41-49.

Lembaga Ilmu Pengetahuan Indonesia (LIPI). (2000). Panduan Lapang Burung-burung di Sumatra, Jawa, Bali, Kalimantan, dan Malaysia. Bogor: LIPI Press.

Odum, E.P. (1994). Dasar-dasar Ekologi, Edisi Ketiga. Yogyakarta; UGM Press.

Tuhumury, et.al. (2014). Keragaman Jenis Burung Berdasarkan Ketinggian Tempat Pada Hutan Desa Rambatu Kabupaten Seram Bagian Provinsi Maluku. Vol. 2 No. 2.

Widyastuti, (2013). Studi Keragaman dan Fungsi Ekologis Pohon Pada Landskap Perkampungan Betawi. Jakarta: IPB Press.

Wisnubudi, (2013). Keanekaragaman Serta Kelimpahan Burung untuk Pengembangan Wisata Birdwatching di Taman Nasional Gunung Halimun. Bogor: IPB Press. 